Western University Scholarship@Western

4-15-2019

\title{
Immunitary Foreclosures: Schelling and British Idealism
}

Tilottama Rajan

Western University, trajan@uwo.ca

Follow this and additional works at: https://ir.lib.uwo.ca/englishpub

Part of the English Language and Literature Commons, and the Philosophy Commons

Citation of this paper:

Rajan, Tilottama, "Immunitary Foreclosures: Schelling and British Idealism" (2019). Department of English Publications. 150. https://ir.lib.uwo.ca/englishpub/150 
This essay discusses how Schelling's work up to 1809 gets appropriated and simplified by, but functions as a fifth column for, British Idealists interested in Naturphilosophie. Focusing on Coleridge (1772-1834) and his friend and executor, the Germanophile professor of anatomy and surgery, Joseph Henry Green (1791-1863), I explore the pressure the life sciences put on philosophy and the constraining of both by religious imperatives that are internal, conceptual censors, and external (cultural and institutional) censors. Though beyond my chronological parameters, Green's protégé, Richard Owen (1804-1892), foremost biologist of the Victorian period before Darwin, is also relevant for idealist biology and transcendental anatomy. Unlike Kant and Hegel, Schelling remained virtually untranslated in nineteenth-century Britain, though he was taken up, and more diversely, in America. But Coleridge, Green, and Owen all read German, while Green and Owen also knew work by Cuvier and Carus. Green, a less complex and peripatetic and more public intellectual figure than Coleridge, met Coleridge in 1817 through Tieck; they read Schelling intensively in 1818 after Tieck arranged for Green to study German philosophy in Berlin with Solger in 1817; and for 10 years after Coleridge's nervous turn against Schelling in 1818, they discussed issues arising from Naturphilosophie. Coleridge's own interest in Schelling began in 1806, and despite later disavowals that when he credited Schelling with a 'revolution in philosophy,' he knew only the 1800 System of Transcendental Idealism (STI), by 1816 he probably owned 11 texts by Schelling.11. Coleridge, Notebooks, 2.2784; Biographia Literaria, 163; and 'Friedrich Joseph Wilhelm von Schelling,' 4.344.View all notes These spanned Naturphilosophie, transcendental philosophy, and religion and included the Freedom essay, and in the following years, Coleridge tried to acquire as much of Schelling's work as possible.22. Coleridge, Collected Letters, 4.665.View all notes

The Coleridgeans were drawn to German Idealism's idea of nature as selfdeveloping but wanted to see a unity of plan in this process. This desideratum culminated in Owen's adaptation of the vertebrate archetype from Carus, which allowed him to 'personif[y]' nature as advancing 'from the first embodiment of the Vertebrate idea ... [to] the Human form,' 'guided by the archetypal light.' 33 . Owen, On Limbs, 86.View all notesBut the tension between natural detail and divine plan is intimated in the 'Recapitulatory Lecture' for Green's 1827 course on the medico-naturalist thinker John Hunter (1728-1793), where Green writes that a 'history of nature' may begin inductively with the 'lowest,' 'nature,' or deductively with the 'highest' or 'First cause \& ground of all,' God.44. Green, 'Birds,' 313; cf. His 1828 lecture in Vital Dynamics, 102-4.View all notes We will return to this history of nature that Green calls 'physiogony'; but if nature is autogenetic, there is no guarantee where it may go. Hence, Schelling speaks of nature 'evolv[ing] itself out of its own powers' in a 'terrible loneliness.' Moreover, 
he sees a 'polarity' in the world-process, which is not a synthesis of opposites but a 'duplicity' and possible 'diremption.' 55 . Schelling, Ages of the World, 104; and First Outline, 39, 139.View all notes Both Green and Coleridge recognize this diremption when they see 'integration' and 'individuation' as 'polar forces' in nature's 'evolution' from the lowest to highest, since in individuation the 'nisus of each detach[es] itself from the preceding or more imperfect States.' 66 . Coleridge, Theory of Life, 507, 515, 557; and Green, 'Birds,' 310.View all notes For if the higher detaches itself from the lower in what Schelling in his 1799 First Outline (FO) calls the Stufenfolge or graduated stages of nature, the lower can also dis-integrate itself from the procession towards the higher. Each nisus can detach itself from the progress of 'nature as subject' or natura naturans, -7 . Schelling, First Outline, 17.View all notesforming objects or hypostases that may start new series that do not form part of an ascent.

Put simply, unity of plan and biodiversity are incompatible. Hence, when the Coleridgeans took over Naturphilosophie's conception of individual organisms and nature as self-organizing, they kept a 'designing power' for God.88. Richards, Romantic Conception, 518.View all notes They were supported in this by the legacy of the Cambridge Platonists, who posited a 'plasticity' in nature, but as a lower power that accounted for a certain blind or random variance under God's distant oversight.⒐ Hunter, 'Plastic Nature,' 202-9.View all notes Significantly in his 1827 Hunterian lectures, Green had said that to deduce a history of nature was a branch of 'Theology,' which he wanted to keep separate from science. But in his 1828 lectures, on the edge of the Bridgewater Treatises commissioned in 1829 to reconcile the new sciences with natural theology, Green drops the bounding off of theology as well as any troublesome references to the 'nisus' of individuation.1010. Compare Green, 'Birds,' 313 with Vital Dynamics, 102-5.View all notes By contrast, recognizing this power of individuation, which Leibniz also saw in the infinite divisibility of monads, Schelling says that within every 'sphere other spheres are again formed, and in these spheres others.' In terms of 'Nature as subject,' these 'individual products' are 'abortive attempts.' 1111 . Schelling, First Outline, 41, 41n, 44. View all notesYet besides this 'perspective ... for the whole of organic nature,' there is also one for the 'individual,' which Schelling feels compelled to 'recover.' To be sure, Nature perceives the individual's 'deviation' as 'disease,' but as Schelling ironically adds, 'life' itself must then be a disease and a 'state extorted from Nature.'1212. Ibid., 158-60, 160n. View all notes

Schelling himself is torn between the universal and, particular, transcendental and natural philosophy. In STI, where nature is 'the unconscious poetry' of 'spirit,'1313. Schelling, System of Transcendental Idealism, 12.View all notes nature's autopoiesisresembles the artistry and 'plastick' power posited by Robinet and Cudworth to accommodate variance within a higher plan. But as 
Schelling gets into nature's details, transcendental and natural philosophy cease to be 'one science' differentiated only by their 'opposite orientation.' ${ }^{14} 14$. Schelling, 'Introduction to the Outline,' 194.View all notes Coleridge himself recognizes that the very concept of self-organization enfolds a possible diremption of natural from transcendental philosophy, when he comments on the dangers of positing 'an unconscious activity that acts intelligently without intelligence.'1515. Coleridge, 'Friedrich Joseph Wilhelm von Schelling,' 4.374.View all notes That Schelling was a plastic, protean thinker who opened these dangers is one reason Coleridge ends his Lectures on the History of Philosophy without discussing Schelling, complaining that he can be rhizomatically found in Kant, Spinoza, Plotinus, and Proclus, thus frustrating 'a true account.'1616.

Coleridge, History of Philosophy, 2.506, 588-90.View all notes Interestingly, Hegel also criticizes Schelling's refusal to be reduced to a single system, 1717 . Hegel, History of Philosophy, 3.515. View all notes even as he ends his own history of philosophy with Schelling as the impossibility of concluding philosophy's history.

Yet paradoxically a simplified Schelling is used by British Idealism to give the life sciences philosophical weight, while inoculating them against the questions catalyzed by the feedback loop between science and philosophy. This involution of philosophy in science also has consequences for religion in the Freedom essay that disturb Coleridge, despite his high praise for this text in 1812.1818. Coleridge, 'Friedrich Joseph Wilhelm von Schelling,' 4.402.View all notesFor unlike the more piecemeal twentieth-century reception of Schelling, Coleridge and Green saw that science, philosophy, politics, and religion form an architectonic in which different fields are so invisibly intertwined that unsettling one part destabilizes the whole edifice. The desired integration of different fields through a closed system of metaphoric transfers is apparent in the way Coleridge and his medical friends Green and John Abernethy adapt physiological to sociopolitical notions of 'constitution,' anxiously making the sciences of nature serve 'spirit,'1919. Green, Vital Dynamics, xxii-iii. View all notes a term they could channel in secular directions without forfeiting its religious aura. Contrarily, the contamination with which other fields threaten religion is apparent in the Bridgewater treatises' concerted plan of neutralizing multiple sciences, with an awareness that bio- and geo-diversity are homologous with polytheism, because they unsettle the idea of a single creation and unity of plan across species and ages.ㄹ⒛ Amundson, Changing Role of Embryo, 63-7.View all notes

In the larger arc of British Idealism's attempt to contain its more speculative, German counterpart and deploy it within this immunitary apparatus, there was a first (Romantic) phase dominated by Schelling and a second (Victorian) phase which selectively took up Hegel. Theorizing the 'self-confuting logic' of the immunitary apparatus, the contemporary philosopher Roberto Esposito suggests 
that in the nineteenth century there was a 'dialectical circuit between political position and scientific research which projected conceptual references from one sphere onto the other.' Through this 'short-circuit' (an example being the way 'constitution' moves between Abernethy's work on constitutional diseases and Coleridge's On the Constitution of Church and State), 'the "political body"' closes 'within itself' against its 'outside,'”2121. Esposito, Immunitas, 130, 147; and Bios, 158. View all notes contracting the intellectual sphere as well. In the first phase, this short-circuit occurs through natural theology as a reconciliation of science and God deeply underwritten by political anxieties. But in the Coleridgeans' attempt to synthesize natural philosophy and religion, Schelling proves a pharmakon. The result in the second phase is a forgetting of natural within political theology, through a turn to Hegel focalized through his logic and theory of the state rather than his aesthetics or philosophy of nature.

Here it is worth mentioning the polymathic, though radically empirical, work of Hunter, who stands behind the urgency of dealing with nature in the first phase. Hunter was an encyclopedic thinker whose work spanned medicine, physiology, comparative anatomy, and geology: one who, in typically Romantic fashion, wanted to create a system but held back from publication and definitive organization. In scope if not style his work rivals the more theoretical projects of Hegel and Schelling in traversing all knowledge in the life sciences. In 1799, the Crown purchased his collection of fossils and healthy and diseased body parts, and the life sciences thus became a national trust, resulting in the Hunterian Museum at the Royal College of Surgeons, Hunterian lecture series, and 'orations' on Hunter's birthday. To complicate matters, though much of Hunter's medico-physiological work was collected and published (but not till 1835), his brother-in-law Sir Everard Home burned Hunter's notes on the specimens in 1823. The general view is that Home plagiarized the work, but he himself said he wanted to protect Hunter from charges of irreligion. In this vacuum, 'Hunter' became a metonym for the problem of how to manage life: practically, by considering the past and future of British medicine, or intellectually, by organizing his work to resolve the insidious question of what constitutes life. Those who wanted to see Hunter's empiricism not as materialism but as demonstrating some kind of 'spirit,' organized and theorized his work according to a combination of Cuvierian taxonomy and the graduated stages of nature. Though the Stufenfolge was not unique to Idealism, Schelling's development of it was crucial to Hunter's philosophical interpreters.

Coleridge is the most interesting here but plays a hidden role, as his Theory of Life (TL), written much earlier,, 222 . The date usually assumed is 1816-1817, but McFarland (2002McFarland, T. 'Prolegomena' to S.T. Coleridge, Opus Maximum. Edited by Thomas McFarland. Princeton: Princeton University Press, 2002. [Google Scholar]) argues that TLwas written in 1819 
('Prolegomena,' ccviii-ix).View all notes was not published till 1848. More in the forefront are Green, who gave Hunterian lectures and orations, and Owen, also a High Church man, who was hired to arrange the collection, becoming sole Hunterian lecturer in 1837..2323. For the religious and political affiliations of Green, Owen and the 'Germano-Coleridgeans' see Desmond, The Politics of Evolution, 26-75, 352-72. View all notes Hunter's work crystallized on the British scene the threat posed by the life sciences to religion and was the object of fierce debates over 'life,' notably the contention between Abernethy and the materialist William Lawrence which sparked Coleridge's text. Yet there is little in Hunter to support an ascent of man where nature gradually sheds the counter-memory or phylogenetic traces of lower organisms, and in FO Schelling only writes this idea under erasure. Though Hunter pre-dates Schelling, Schelling knew his work, and just as Naturphilosophie proved a thorn in the flesh of transcendental philosophy, Hunter was a fifth column in British science.2424. See Rajan, 'Asystasy,' for elaboration, as well as discussion of how Hunter and Schelling can be connected. View all notesAmong the concerns he shares with the Germans is an interest in the self-organization of life as it develops from matter in a process that has no clear evolutionary line and an uncertain sense of the relation between matter and 'spirit' (as the name for a vital principle that is obscure, ungrounded, and aleatory). Related to this is his sense that normal and pathological life processes may be entwined, evidence for which lies in his many surgical case studies, where life and mortification come perilously close. In the appendix on disease in Schelling's FO and the last section of Hegel's Philosophy of Nature, we find a similar proximity between disease and life that imperils the movement from nature to spirit. Nor does Hunter's physiology support the graduated series of 'powers' and 'functions' that Schelling and Coleridge wanted to find in bodies..2525. Schelling, First Outline, 149, 159; and Coleridge, Theory of Life, 495, 526. View all notes Moreover, in general Hunter's work on the body's ramifying subsystems, paralleled in Schelling's physiology in $F O$, forces us to rethink the tangled nature of systems, raising problems for the all-encompassing intellectual system that Coleridge sought in German Idealism²626. Coleridge, Collected Letters, 4.667.View all notes: problems mirrored in Coleridge's attempts to crisscross innumerable fields of knowledge in his Notebooks.

Green uses Schelling expediently to contain Hunter, but together they make an explosive cocktail. Hunter gives empirical depth to Schelling's 'tormented idealism,'ㄲ27. Krell, Contagion, 24. View all notes while Schelling helps to phrase philosophically the issues raised by Hunter's radical empiricism. Thus in British Idealism's second phase, it becomes easier to turn to a rationalized Hegel, purged of his philosophy of nature, which was left untranslated till 1970.2828. William Wallace translated Parts 1 and 3 of the Encyclopedia $(1873,1894)$ but not the Philosophy of Nature. Twentieth-century translations of the three Jena systems also scrupulously omit the sections on nature.View all notes Of note 
here is work by Stirling, McTaggart, Caird, Bosanquet, and others. In this phase, Schelling is still read (and indeed Oken and Oersted were translated), but his volatile Naturphilosophie is firmly contained as a 'subordinate or applied department' of 'transcendental philosophy' by commentators like John Watson who exported British Idealism to Canada.2929. Watson, Schelling's Transcendental Idealism, 92. View all notes Indeed, Naturphilosophie becomes a way of marginalizing Schelling, as the Hegelian state could realize spirit more safely. Just as the state and ethics close off the dangers of Naturphilosophie, Hegel's logic is used to resist the existential and esoteric tendencies of the late Schelling, whose religion was insufficiently allied with civil society. That 'Hegel' becomes more respectable for Anglo-American philosophy in the long run should not distract us from their early continuity in the mission of British Idealism. For as natural theology mutates into political theology, Hegel does the figural work intended for 'Schelling,' only better, because he has been better streamlined.

For Esposito, 'political-theology,' or what Carl Schmitt discerns as the persistence of theological structures in modernity, is part of the social body's selfprotective immunitary apparatus. These structures, including the corporation of a college like the RCS, considered as 'a collective person' or 'legal body' in which power passes uninterruptedly from Father to Son, survive so invisibly in discourses and institutions that one is unaware of being incorporated in their 'web.' Consequently, though theology and secularization seem opposed, the two remain within 'the same horizon.' The isomorphism of the political and theological works bilaterally, as theology determines and is determined by the political and its domains: class, structures of authority and thought, and hierarchies of mental faculties and academic fields. British Idealism's turn to Hegel because he was more modern exemplifies this rechannelling of theological into politico-intellectual structures that do not give up a hidden religious validation. This transfer, as Esposito suggests, occurred more efficiently in Protestantism, which had preserved theology as political theology, than in Catholicism which had to undergo a 'tragic revolutionary break' to enter modernity, exposing the 'aporetic' way that politics and theology are 'bound together' in dis-correspondence. .3030 . Esposito, Two, 3, 23-24, 33, 54-5, 77.View all notes Doubtless this is why the mid-Victorian wave of British Idealism, though in some cases theologically centered, never took up the late Schelling. For although political theology was in play in Schelling's appointment to Hegel's chair, Schelling's work from the Freedom essay onwards revolves around this dis-correspondence, where philosophy and religion are each used to think the other from the outside.

Green is a neglected figure in the transition within British Idealism. For it was he who laid the basis for Germano-Coleridgean thought as a political theology by passing on his mantle to Owen and constructing a clerisy with Coleridge as Father in subtitling his last book as 'founded' on the master's 'teaching.' 
Spanning the Romantic and Victorian periods, Green also effects the Aufhebung of natural into political theology. Green gave the Hunterian lectures from 1824-1828, but it was not till 1840 that he published Vital Dynamics, a retrospect which combined his Oration of that year with earlier papers, including the last (1828) version of the 'Recapitulatory Lecture' for his courses, which forms the basis of his Oration. Vital Dynamics is followed by Green's second Hunterian Oration, Mental Dynamics (1847), and then the posthumous Spiritual Philosophy (1865), edited by his pupil, which brings Coleridge's 'teaching' to the threshold of British Idealism's second phase.

Green knew the work of Kant, Schelling, and Carus. But since he went to Berlin in the year Solger helped appoint Hegel and owned a copy of the Logic, he may also have had some knowledge of Hegel. An attenuated Hegelian influence is suggested by the fact that the movement from nature to spirit enacted between Vital and Mental Dynamics is more Hegelian than Schellingian. To be sure the transition is titular, since Mental Dynamics has little to do with psychology or any other 'philosophical' sciences. Also reminiscent of Hegel is Green's interest in an encyclopedic Bildung that traverses all the disciplines, since Mental Dynamics combines the Idealist program with the trivium and quadriviumto outline a general curriculum for the education of a medical clerisy. Again, Green's orientation is pragmatic, not speculative, as he (perhaps) added on a simplified Hegel to a Platonised Schelling. Green, Vital Dynamics, xxi.View all notes

Vital Dynamics aims to recognize Hunter as a 'philosophical physiologist' in a Kantian sense and thus to elevate the life sciences into philosophical sciences with higher aims than the pragmatic ones emphasized by other orators. 3232 . Ibid., v-ix, xiv-xv. View all notes For this purpose, Green invokes the 'dynamic' philosophy of the Germans and specifically Schelling. Alluding to $F O$, which he read with Coleridge, Green elides its complexity by glossing it through Schelling's more transcendentally idealist comments, in On University Studies, on comparative anatomy as the unity and affinity of all organisms. $\frac{33}{33}$. Ibid., $38 n$.View all notes Crucial to Green's organization of scientific knowledge is the schema of physiography, physiology, and physiogony which he used in two of his lecture series. Physiography is mere natural history or natura naturata.

Physiology studies the 'laws,' 'powers,' and 'forces' common to 'living bodies' and is natura naturans since, although Green omits plants from his Naturphilosophie, he does evoke 'Nature' in a general sense. Though Green saw his lectures as mainly physiographical, it is physiology that moves beyond phenomena, making biology a philosophical and not just empirical science. But the third and most important mode is physiogony, which projects Nature 'as an agent, acting under the analogy of a will,' thus making the jump from purposiveness to teleology. Physiogony studies how nature 'labours in birth with man,' working up from 
'the polypi to the mammalia,' and making nature a 'preface and portion of the history of man,' and 'branch of self-knowledge.' Its 'History of Nature' is a series of Aufhebungen, which allows us to discover in the past, as 'so many embryonic states of the organism,' the 'solution of the present, and in both the anticipation of the future. ${ }^{34} 34$. Ibid., $101-4$. View all notes

Green gets two of his terms from Kant, but Kant's use of physiogony in a footnote is inconsequential. More relevant is Schelling, who complains that Kant's Naturgeschichte is a mere Naturbeschreibung. Schelling thus wants to give 'natural history' 'a much higher meaning,' that of a 'history of Nature [eine Geschichte der Natur selbst].' Hence his teleological hypothesis of the Stufenfolge whereby Nature 'brings forth the whole multiplicity of its products through continuous deviations from a common ideal' which it realizes 'in the whole' rather than the 'individual.' 3535 . Schelling, First Outline, 53; for a fuller discussion see Rajan, 'Evolution and its Resistances,' 161-2.View all notes Green specifically responds to Schelling when he describes 'Natural History' as 'a misnomer, an erratum in the nomenclature of science,'3636. Green, Vital Dynamics, 107.View all notes naming a new science, physiogony, to ground the analogy of nature and spirit as an evolutionary sequence. Coleridge makes a similar comment on the day Green first theorized physiogony in his 1827 'Recapitulatory Lecture.' But otherwise, Coleridge's use of physiogony is theological and not natural-historical, and he does not put it into a disciplinary series including physiography and physiology. 3737 . Coleridge, Notebooks, $5.5478,5489,5510,5518,5522$. View all notes It seems, then, that Green is responsible for naming this new science. For not only is Green more teleotheological than Schelling, and not only does he hypostatize Schelling's speculation, using it to narrativize Hunter, whose work is more like the networks of fields in the Outline itself. Throughout Vital Dynamics, Green also simplifies and streamlines Coleridge, to make natural theology the foundation of political theology. Thus where Coleridge sees the two tendencies in nature's evolution individuation and integration - as polar forces, Green synthesizes them.3838. Coleridge, Theory of Life, 515; and Green, Vital Dynamics, 38-9.View all notes And it is Green, more than Coleridge, who directs Abernethy's work on constitutional diseases towards political and social constitution,3939. Green, Vital Dynamics, xxii-iii.View all notes making explicit the political theology that had always underlain natural theology.

In the light of Mental Dynamics, Vital Dynamics seems a retrospect that organizes the life sciences to move beyond them. This recapitulation is possible because it distills Green's previous work without the details of his lectures from the 1820s. Green's evocations of Idealism, anglicized under the cloak of 'Hunter,' are similarly schematic. Where in Hegel's Encyclopedia nature keeps returning in the sciences of spirit (anthropology and psychology), Mental Dynamics focuses 
on education, not philosophy. Recapitulation in biology is a deeply economic concept, sparing nature from having to go through all the stages again in each individual organism, and sparing thought from what Coleridge calls 'incipien[ce].' 4040 . Coleridge, Notebooks, 4.4517. View all notes Coleridge is more fraught, the key text being $T L$, published without the knowledge of Green, who might not have wanted to represent Coleridge by anything unsystematic. 141 . McFarland, 'Prolegomena,' cxlv-vi. View all notesWhile commentators assume Green did not know $T L, 4242$. Levere, however, suggests Coleridge revised $T L$ in conjunction with Green's 1824 Hunterian lectures (Poetry Realized in Nature, 44-5).View all notes Vital Dynamics responds so closely to it that it seems rather a silent natural-theological correction of Coleridge.

Coleridge is more complex. His reading of Schelling was ambitiously interdisciplinary but is best known for his borrowings from STI in Biographia Literaria ( $B L)$. According to Orsini what attracted Coleridge in $B L$ was Schelling's 'inclusion of nature in the system of absolute mind': his 'dynamic philosophy,' which repudiated 'realism' by making nature 'unawakened mind' and mind 'nature that has achieved' self-consciousness.4343. Orsini, Coleridge and German Idealism, 198-200.View all notes But the texts supporting this reading - STI and the 1799 Introduction to the Outline - do not represent the Naturphilosophie, as Schelling worked simultaneously with multiple possible systems, this radical openness being the 'freedom' he confers on the 'absolute subject' in his Erlangen Lectures.4444. Schelling, 'Nature of Philosophy,' 217-20.View all notes Though this seems unrecognized by Coleridgeans, FO and its Introduction are radically different texts: the latter is a supplement published after the text it introduces and tries to put what Hegel describes as nature's 'ever-increasing wealth of detail' which is 'recalcitrant to the Unity of the Notion' back into a system of identity. 4545 . Hegel, Philosophy of Nature, 444.View all notes As such, its desired correspondence of natural and transcendental philosophy is hypothetical. Indeed, when Schelling says in FO that to 'philosophize about nature means as much as to create it,' this is no statement of correlationist idealism, but indicates that everything is in construction, or that there are no Kantian a priori categories of mind. Mind is a fold in nature, and as it thinks about nature, the forms that mind takes are created by new forms in which nature causes it to think. But this can happen only if mind constructs a nature that is itself in 'configuration,' for it would be 'impossible to get a glimpse of the internal construction of Nature' if we did not attempt a speculative 'invasion ... through freedom,' as a 'question put to Nature' to which it responds.4646. Schelling, First Outline, 5-6; and 'Introduction to the Outline,' 196-7.View all notes It is in this doubly constructivist sense, and not in the conventional sense of identity assumed by Coleridgean commentators, that Schelling says 'the system of nature' is simultaneously 'the system of our mind.' 4747 . Schelling, Ideas, 30.View all notes 
For Schelling transcendental and natural philosophy are potencies of each other, quantitatively different, perhaps also qualitatively, but not in a hierarchical way. Coleridge, by contrast, is a dualist. Or he is uncertainly a monist in the locodescriptive poetry and scientific prose (including letters) which are his equivalent of the Naturphilosophie, but a dualist in his need to reassert a higher term: God, mind, or imagination. Thus in $B L$, the primary imagination or perception is a 'repetition' in the human mind of the 'eternal act of creation in the infinite I AM' whose self-grounding is mirrored in a Fichtean I that Coleridge calls will, while the secondary or aesthetic imagination is an 'echo' of the primary. Lest even this schema of emanation rather than potencies veer too close to the monism that is also what draws him to the dynamic philosophy, Coleridge then asserts an absolute dualism between imagination as vital and fancy as mechanical, and between imagination and the 'objects' it 'struggles' to idealize and unify, which are 'fixed and dead.'ㅃ48. Coleridge, Biographia Literaria, 3045.View all notes This division between organic and inorganic would be unthinkable for Schelling. The theory of imagination implodes because it cannot hold the poles of a dynamic philosophy and an immunitary dualism together.

Nevertheless, the common wisdom accepts Coleridge's own ingenuous explanation that when writing $B L$ he was misled by having read only $S T I$, otherwise Schelling himself would have put him 'on guard.' 4949 .

Coleridge, Collected Letters, 4.874.View all notes Yet we know that by 1812 he had also read the Freedom essay. When Coleridge later read Schelling intensively with Green in 1818, he supposedly rethought his earlier, undigested enthusiasm, whether it was Schelling's particularly volatile idealism or his Naturphilosophie that stirred Coleridge's religious anxieties. Writing to Green, he commented that 'as soon as [Schelling] commenced the Objective or Naturwissenschaft, he gave the Slip' to the I Am and in 'his Jarbücher der Medicin fairly involved it' in the It Is, leaving 'both in the Lurch.' 5050 . Ibid., 4.874. View all notes At this point, even the transcendental philosophy that seemed so 'revolution[ary]' in BL5151. Coleridge, Biographia Literaria, 163. View all notes was bothering Coleridge, as he sensed that it contained its own unravelling into nature. Thus in new marginalia on the Introduction to the Outline, he takes aim at Schelling's claim that transcendental and natural philosophy are 'one science, differentiated only by the opposing orientations of their tasks.' 5252 . Schelling, 'Introduction to the Outline,' 194.View all notes He sees Schelling's 'unconscious activity that acts intelligently without intelligence' as a contradiction, accusing him of not distinguishing 'primary' from 'secondary' or 'reflective consciousness.' 5353. Coleridge, 'Friedrich Joseph Wilhelm von Schelling,' 4.374. View all notes Of course this is the point of FO's extraordinary experiment in grasping nature as pure primary process, which can be done only through a reflective invasion that is itself reconfigured by this process. 
What concerns Coleridge even in the transcendental philosophy is that if nature is immanently self-organizing, if nature develops into intelligence rather than under its direction, then mind too risks becoming autogenetic and escaping the control of a higher term. Put differently, Schelling's notion of dynamic evolution is oriented to growth, and this growth and the growth of the mind it opens up (to evoke Wordsworth) threaten to unbalance the argument from design. Coleridge thus reacts against 'making Nature absolute.' He further complains that Schelling does not posit a 'genesis' of matter and motion (and thus a divine origin) but assumes 'the eternity of the material universe' in 'a succession which is it's [ $\mathrm{sic}$ ] own predecessor'; consequently 'God is not self-sufficing ... not GOD, but a part of the universe, nay a product of the same. This indeed Schelling has dared assert in his Denkmal.' Put differently, Schelling introduces 'polarity' into the 'unity of a perfect Will' or 'Godhead,' polarity being not the expansive and contracting drives in nature that Schelling often evokes, but the philosophical poles of 'Transcendental Idealism ... and Nature.'5454. Coleridge, Notebooks, 3.4449; and Collected Letters, 4.873-4.View all notes This bi-polar God and the bi-polar mind needed to comprehend him, go far beyond any comfortable pantheism of the 'One Life,' making God a 'life,' 'subject to suffering and becoming.' 5555 . Schelling, Freedom, 66. View all notes

Coleridge's critique goes to the heart of Schelling's work which, in turning to the 'ideal part' of philosophy in the Freedom essay, 5656 . Ibid., 4.View all notes performs a reverse Aufhebung that makes the philosophy of nature a feedback loop which involves the very ground of philosophy in its ungrounding. Green chose to ignore this detailed reading of Schelling in the higher service of inventing a philosophical authority to contain the religious threat posed by the life sciences. But we should not too decisively use Coleridge's ill-tempered letter to Green about the 'rotten parts' and 'vacua' of Schelling's 'foundation' to construct Coleridge's thinking in the same clear line. Coleridge turned against Fichte and then returned to the bulwark Fichte provided.5757. Coleridge, Collected Letters, 4.793, 873-5.View all notes His speculative waverings around 'Schelling' are rhizomatically threaded through letters and notebooks as well as the persona he adopted in published work that uses political theology to put fences around natural philosophy: namely Aids to Reflection and Church and State. Coleridge does indeed grow more critical of Schelling, and commentators like Raimonda Modiano have therefore seen him as completing his own very different system or, in Paul Hamilton's intriguing argument, the system of which the Schelling of the positive philosophy was in search.5858. Modiano, Coleridge, 160, 186-204; and Hamilton, Coleridge and German Philosophy, 122-3.View all notes But 'Schelling' is better seen as a space for projecting, disavowing, yet secretly holding onto solutions and irresolvable issues about the relationship among idealism, nature, and religion. 
For there is nothing systematic about Coleridge, whose notebooks exemplify Schelling's claim that the desire for a system indicates that knowledge 'does not exist in a system' but is an 'asystaton,' 'in inner conflict.' Schelling may want to overcome this asystasy in unity, but also argues that this 'irresolvable' conflict must be 'developed in every possible direction,' which means that a 'truly free philosophy' has to 'leave everything,' even 'God.'5959. Schelling, 'Nature of Philosophy,' 213, 217. View all notes Clearly this would not suit Coleridge. Yet the fact that Coleridge wrote an essay on scrofula at the same time as the vitalist $T L$ mirrors both Schelling's inclusion of an Appendix on disease alongside the Stufenfolge in $F O$, and the similar problems about vitality and (de)generation raised by Hunter's corpus. Nor does Coleridge overcome this duality, as he continues to read and translate German medical texts while writing Church and State. Thus I suggest that Schelling's asystasy is the underside of Coleridge's political theology. The nervous structure of the oxymoron 'political theology' can be seen in Coleridge's early poem 'The Eolian Harp,' which flirts with pantheism, admittedly a simple pantheism that imagines a pre-established harmony in 'all of animated nature' (I.44), and not the ontologically devastating exposure of 'God' to finitude we find in Schelling's Freedom essay. At the end, Coleridge invokes a higher term to close off his 'vain Philosophy' (I.57), or rather an ambiguously gendered placeholder for this authority, his wife, whom he addresses as 'Meek daughter in the family of Christ.' (I.53). The awkward language suggests Coleridge's uncertain relationship to this 'family' that is both required and stifling and indeed suggests Coleridge's precarious participation in all the families he would construct: personal, scientific, and theological.

A similar misfit between framing and content drives $T L$ which, though unpublished, continues to worry Coleridge's thinking with the aporias of Schelling's work. Coleridge was drawn to German thought because of its 'Encyclopedic Breadth,' and even in mid-1818 saw Schelling as unifying subjective and objective poles. That this project may be 'too ambitious' 6060 . Coleridge, Collected Letters, 4.667, 792, 863. View all notes is the sign that encyclopedic breadth is precisely what opens up an unavoidable asystasy. German thought spurred Coleridge to imagine his own organization of knowledge, which in mid-1818 he rethought as a 'descent' from Theology, through Ethics and Logic, to Zoology and Physics.6161. Ibid., 4.864.View all notes But the hints towards an organization of knowledge in $T L$ take the more Idealist form of an 'ascent': a form based on Schelling's Stufenfolge and used by Hegel to anchor an ascent of disciplines. In TL Coleridge, while tracing nature's evolution from inorganic to organic and from polypi to mammalia also gestures towards an epistemic ascent through the corresponding disciplines of physics, geology, and physiology. In an uncanny coincidence with Hegel, each science forms a 'circle' that is an 'arc' or 'station' in the 'absolute science of Life,' from whence begins a 'new series beyond ... physiology' 6262 . Coleridge, Theory of 
Life, 516, 519n, 551.View all notes: what Schelling calls the ideal as opposed to real series. The issue of ascent vs. descent is that of an immanently unfolding development vs. a transcendentally guaranteed deduction of both life and knowledge.

At the heart of $T L$ is what Schelling calls the Stufenfolge, by which nature organizes itself in an ascending scale of complexity, through 'continuous deviations' from the 'ideal,' but as 'one organism [Organisation] inhibited at various stages.' 6363 . Schelling, First Outline, 43, 53.View all notes This dynamic evolution is an adaptation of the more static hierarchy of classes in the Chain of Being, but for both Schelling and Coleridge, it is an 'idea,' and not the actual biological evolution envisioned by either Darwin.6464. Ibid., 49.View all notes The immediate occasion for TLwas the Abernethy-Lawrence debate over religion vs. science, focalized through Hunter's work. The Museum contained everything from fossils to preserved parts of living creatures, thus opening the porous borders between organisms of which man is only one species. Responding to this array which was still being organized in the 1830s, Coleridge asks what 'life' is, answering this question both physiologically and physiogonically, in Green's later terminology. Physiologically, Coleridge concurs with Hunter that life cannot consist in organization, which may precede it but is merely mechanical. But where Hunter decouples life and organization, making the vital principle something aleatory and unspecified, for Coleridge organization also remains a minimal condition of qualitative life: a crystal is superior to an amoeba. It is this which leads to his strong emphasis on 'individuation' as the combining of parts into a whole, but within a 'progressive' 'ladder' of being or 'gradative evolution,' Green's term for the Stufenfolge which anchors his physiogony. 6565 .

Coleridge, Theory of Life, 510, 533; and Green, Vital Dynamics, 39.View all notes

But Coleridge has difficulty with this paradigm that tries to immunize a normative 'nature' against a 'life' that, for Schelling, exceeds it.6666. Schelling, First Outline, $62,160 \mathrm{n}$. View all notes For in nature's proliferating details, the corals and polypi complicate the ascent from vegetation to animalization necessary to individuation. Indeed, Coleridge cannot put vegetation and animalization in a sequence and sends them in different, branching directions; yet they also meet in the corals and polypi, confusing what he wants to separate. 6767. Coleridge, Theory of Life, 538-9.View all notes Nor does the increasing complexity of organisms align with their increasing integration, as Green knew it must do for physiological constitution to provide an argument from design that supports the health of the body politic. For the body's subsystems threaten the balance between individuation and integration. Thus in 1822, Coleridge writes of the relations of 'the different parts of the Body' to the 'nervous system' and 'the nerves themselves to the Brain' and says that 'the polypus nature of every nerve' means that each part not only has 'relations to its centre' but is 'a center in itself.' 
It seems then that the human body is a 'network' of hyperindividuations rather than a 'graduated series of functions.' 6868 . Coleridge, Notebooks, 4.4865; and Theory of Life, 539.View all notes For Schelling too, it proves impossible to achieve this graduated series of functions fused into 'ONE force,' as the body ramifies into 'individual systems of specialized excitability' that make 'organization' an 'involution' of 'system within system.' ${ }^{6969}$. Schelling, First Outline, 127, 141, 149.View all notes

Hunter is supposed to resolve these problems, and contemporaries tried to narrativize his cabinet of curiosities as a natural history museum that demonstrates the Stufenfolge. But there is no naturalized theodicy in Hunter's empiricism, which led him to collect as many diverse, mutant specimens of life as he could. Coleridge therefore turns from the Museum to Hunter's 'writings' to 'guid[e]' him towards the 'unity of the Creator.' But these writings are full of 'obscurities' and 'contradictions.' Indeed, Hunter's physiology presents a network of nerves, blockages, and anastomoses that figures the very structure of his writings. So two years later, in the Essays on 'Method,' Coleridge turns back from writings where Hunter never found 'the compleating Word' to the Museum, where, absolved from language, he constructed the 'idea' for 'scientific apprehension out of the alphabet of nature.'7070. Coleridge, Theory of Life, 586; and The Friend, 1.474, 474n1.View all notes This mystification, and the hermeneutic circling between the writings and Museum as supplements to each other, exposes Hunter as an inadequate prosthesis, sustained by what others projected onto him.7171. Coleridge could not have read much by Hunter on life. The published work available by 1816-1819 was on gunshot wounds, venereal disease, and teeth but not comparative anatomy. Coleridge probably had an impression of Hunter's theories from John Abernethy, who sanitized him for his own purposes. Even organization of the Museum did not begin in earnest till 1823.View all notes Thus, the 'august temple' of Hunter's corpus resembles nothing more than the 'Gothic cathedral' Coleridge uses to figure his own halfunwritten theory of imagination in the contemporaneous $B L$. While $T L$ was simply not published, in BLColeridge actually published a letter from a 'friend' advising him not to publish his theory.를. Coleridge, Theory of Life, 586; and Biographia Literaria, 300-4.View all notes This curious subterfuge draws attention to the deferral of publication as a way of writing under erasure. Schelling enters both these texts as a zone of disavowal, openings, and untraversed difficulties. For the infamous plagiarisms in both texts are a way for Coleridge not to put in his own words a unifying idealism that cannot be grounded in Schelling either.

Plagiarism holds together in a bipolar short-circuit a simultaneous enthusiasm for and doubt about this unity.

In $T L$ as Hunter proves inadequate, Schelling and Naturphilosophie are introduced to support the One Life. But again, Schelling is a hypotyposis, and the 
fact that he is nowhere mentioned intimates an anxiety about the Pandora's box he might open: a danger intrinsic to any idealism that wants to be a realism. Yet Schelling is throughout the text in the language of indifference and polarity, which continues in Coleridge's work well after 1816. More specifically FO is in the background of $T L$ and is particularly unsettling to any pure idealism because it goes beyond the still abstract dynamic physics of Ideas for a Philosophy of Nature and takes up the history of nature as the complex (de)construction of this very idea of a history. Though Coleridgeans only discuss the Introduction and never FO, it was bound and annotated with the former in the copy Coleridge read. It enters $T L$ in the tension between a 'positive' force of 'attachment or reduction' into the universal life and a force of 'detachment': a 'negative' and 'limitative power, constantly acting to individualize' and 'figure the former.' The

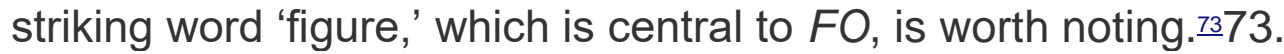
Coleridge, Theory of Life, 515, 557; and Notebooks, 3.4449. If Coleridge did indeed write $T L$ in 1819 (see note 22 above), he would just have been rereading FO.View all notes Finally, of all Schelling's texts, it is FO that most fully works through the Stufenfolge.

For although Schelling does touch on the Stufenfolge in STI, ,7474. Schelling, System of Transcendental Idealism, 122-6.View all notes in making it a preface and portion of the history of spirit, he avoids the conceptual and material details in FO that complicate this history, which are everywhere in $T L$ and the Notebooks long after 1818. Importantly, in FO, Schelling cannot ground the Stufenfolge. Though it is his favored system, it is only one of many possible systems, unsettled by his 'dynamic atomism,' his uncertainty about the role of chemistry, and his volatile physiology described above. At the center of $F O$ is the tension between the 'universal organism' of nature and the individual which is a 'limit to its activity,' which nature 'labours to destroy.' 'Individual natures' that detach themselves from a gradative evolution are 'misbegotten attempts,' even while this 'separation' of botched products from the worldprocess is necessary for deducing the Stufenfolge, since without it these entities would not be 'permanent' and thus discernible as individual stages. $\frac{7575}{}$. Schelling, First Outline, 35, 39-41, 53-4.View all notes But since Coleridge, more than Schelling, also makes individuation the motor of the Stufenfolge, it seems that the individuation which forwards dynamic evolution holds it back, as individual natures develop independently, resisting the will in nature. Coleridge tries to avoid this problem by positing something like a Hegelian Aufhebung to theorize a logical evolution that simulates a material evolution. Discussing the superiority of fish to insects, he also discerns an inferiority in their mode of impregnation and concludes that every 'grade of ascension' is accompanied by 'an apparent retrograde movement' but that when nature 'drops a faculty' she always 'pick[s] it up' again at a higher level.676. Coleridge, Theory of Life, 5468.View all notes Thus 'in the idea of each power, the lower derives 
it's intelligibility from the higher,' while 'each higher implies a lower in order to it's actual existence [sic].' In a fragment on 'The Scale of Life,' he also writes that 'parts are seen' whose 'full purpose' is 'realized higher up in the scale,' so that the higher finds its 'history' in the lower which is a 'vita uterina,' 'prophetical' of the higher..7777. Coleridge, Collected Letters, 6.597-8; and Scale of Life, 1194. View all notes

Yet the details of the Stufenfolge unsettle the paradigm. This complication also disturbs any 'Stufenfolge' of the 'Wissenschaften,' 7878 . This is Schelling's phrase in 'Vorlesungen' (261). The English translation in On University Studies (55) is imprecise.View all notes hence the idea does not appear in later published work, which only discusses the relation between life and organization. 979 .

Coleridge, History of Philosophy, 2.524-5.View all notes Hence also why a 'descent' of the disciplines from Theology seemed safer than an ascent in 1818, and why in the Encyclopedia Metropolitana, which was completed by others including F.D. Maurice, the volumes follow an ascent through the sciences of spirit, followed by a descent into those of nature, and then an array of other fields.8080. Coleridge dissociated himself from EM, re-publishing his Introduction as the Essays on Method in The Friend. However, it is not the arrangement of volumes that annoyed him, but their mixed systematic-alphabetic arrangement, which brought EM closer to the Encyclopedia Britannicawhich it was supposed to counter. View all notes The Metropolitana was a conservative reaction not only against the more modern Encyclopédie and Encyclopedia Britannica, but also against the Idealist encyclopedics of Hegel, Schelling, and Novalis. But in unpublished work from 1822-1828, Coleridge remained fascinated by an ascent of life, whose problematic nature made letters, fragments, and notebooks the appropriate place for his protean speculations. As a philosopher of science, Coleridge wanted 'evolution as contra-distinguished from apposition, or superinduction ab aliunde.'8181. Coleridge, Collected Letters, 6.599.View all notes In the process, he was sensitive to the fact that life could behave pathologically as well as normally, and less inclined than Abernethy and Green to bracket disease as an aberration from health. That Coleridge wrote an essay on scrofula alongside the vitalist $T L$ mirrors Schelling's inclusion of an Appendix on disease alongside the Stufenfolge in FO, whose devastating consequences for freedom Krell outlines. .8282 . Krell, Contagion, 74-6, 94, 112-14.View all notes

Returning to the disciplines, the problem posed by a descent is that it is, finally, 'superinduction.' So Coleridge continues to speculate after 1818 on an ascent from physics to zoology to theology, wanting a quasi-material QED in the form of an evolution. 8383 . See note 40 above. View all notes But the problem here is philosophy. One of Schelling's differences with Jacobi in the Pantheismusstreit had to do with Schelling's belief that one could not have theology - the summit for Coleridge - without philosophy. Philosophy, Coleridge 
writes in a notebook entry that moves from the scale of nature to the scale of disciplines, is not a 'Science; but a Supplement of Science,' originating 'in the feeling of a desideratum not supplied by any one Science' nor the sciences collectively. 'Supplement' does not mean, as it does elsewhere, that philosophy is a handmaiden in the 'realization' of another science. Yet although philosophy here arises from a lack, Coleridge still wants to think it progressively, writing that it has three stages: 'incipient, progressive, and conclusive or final.' 8484 . Ibid., 4.4517, 4673. View all notes Nevertheless, it is the incipient that holds his attention, as a desideratum of 'self-seeking' rather than 'self-finding,' 'a residuum of darkness common to all' sciences.8585. Coleridge, Collected Letters, 6.599; and Notebooks, 4.4517 (cf. Collected Letters, 4.863).View all notes

Thus Coleridge writes that if theology fails 'in its professed Object' of solving 'the Problems left unsolved' by lower sciences, including their 'darkness or residua,' its failure as 'the Science of Sciences ... gives rise to incipient Philosophy.' We are not dealing here with a science 'sink[ing]' into a lower one, in order to be sublated back into a 'circle' as the lowest point is brought up to the 'apex.' ${ }^{86} 86$. Coleridge, Theory of Life, 519n. View all notesWe might expect such an Aufhebung, which Coleridge earlier in the entry attributes to the scale of nature. But since philosophy is not a science, though not entirely 'heterogeneous' to science, it cannot be sublated; it cannot simply be made the 'transit from paganism to religion. '8787. Coleridge, History of Philosophy, 1.285-6. View all notes To adapt Foucault, philosophy is at once 'essential and inessential-a border that is peripheral to the centre, but which never stops referring to and interrogating it.' 8888 . Coleridge, Notebooks, 4.4517; and Foucault, Introduction to Kant's Anthropology, 120.View all notes Philosophy is the unsettling margin that accompanies every science which sees itself as progressing towards conclusiveness, yet always risks falling back into incipience. This 'meta' function does not make it the science of sciences, but rather means that it is the interior and residuum of all sciences because it always exceeds and cannot entirely be subsumed into other sciences. This is what we saw in $T L$ when Coleridge added philosophy to the life sciences to make them progressive, but in the process elevated material details to the level of philosophical problems that resulted in the text falling back into incipience. It is also what he fears happening to theology. For although Coleridge also says that philosophy exists only when theology fails, and though he insists that theology is self-grounding because God is 'the ground of its own existence,' he ends by writing: 'Thus, the failure of Theology ... gives rise to incipient Philosophy'(emphasis mine). .8989 . See note 40 above.View all notes Buried somewhere in this entry is also Schelling's profound complication in the Freedom essay of what it means for God to be self-grounding, namely that if God is the ground of (his) existence, then God contains the ground, and is in the ground of which he is the ground. 090 . Ibid., 4.4728.View all notes For Schelling, too philosophy bears on 'all things' and so cannot be limited to being 
a Fachwissenschaft or defined subject.9191. Schelling, On University Studies, 7981. View all notes And it is as philosophy that 'Schelling' continues to haunt Coleridge. Apart from direct references to him, well after the 'turn' in 1818, the language of polarity, indifference, ground, powers, and copula is threaded through the Notebooks 2292 . For Coleridge's continued reading of Schelling, see Notebooks, 4.4641, 4776, 4778, 4839 See 4538, 4641, 4663, 4776, 4784, $4797,4843,4998,5243,5290,5406$, etc. View all notes and carries with it a residuum of darkness that draws Coleridge's differences from Schelling, on which his natural and political theology are based, back into incipience.

\section{Disclosure statement}

No potential conflict of interest was reported by the author.

\section{Notes}

1. Coleridge, Notebooks, 2.2784; Biographia Literaria, 163; and 'Friedrich Joseph Wilhelm von Schelling,' 4.344.

2. Coleridge, Collected Letters, 4.665.

3. Owen, On Limbs, 86.

4. Green, 'Birds,' 313; cf. His 1828 lecture in Vital Dynamics, 102-4.

5. Schelling, Ages of the World, 104; and First Outline, 39, 139.

6. Coleridge, Theory of Life, 507, 515, 557; and Green, 'Birds,' 310.

7. Schelling, First Outline, 17.

8. Richards, Romantic Conception, 518.

9. Hunter, 'Plastic Nature,' 202-9.

10. Compare Green, 'Birds,' 313 with Vital Dynamics, 102-5.

11. Schelling, First Outline, 41, 41n, 44.

12. Ibid., 158-60, 160n.

13. Schelling, System of Transcendental Idealism, 12.

14. Schelling, 'Introduction to the Outline,' 194. 
15. Coleridge, 'Friedrich Joseph Wilhelm von Schelling,' 4.374.

16. Coleridge, History of Philosophy, 2.506, 588-90.

17. Hegel, History of Philosophy, 3.515.

18. Coleridge, 'Friedrich Joseph Wilhelm von Schelling,' 4.402.

19. Green, Vital Dynamics, xxii-iii.

20. Amundson, Changing Role of Embryo, 63-7.

21. Esposito, Immunitas, 130, 147; and Bios, 158.

22. The date usually assumed is 1816-1817, but McFarland (2002McFarland, T. 'Prolegomena' to S. T. Coleridge, Opus Maximum. Edited by Thomas McFarland. Princeton: Princeton University Press, 2002. [Google Scholar]) argues that TL was written in 1819 ('Prolegomena,' ccviii-ix).

23. For the religious and political affiliations of Green, Owen and the 'GermanoColeridgeans' see Desmond, The Politics of Evolution, 26-75, 352-72.

24. See Rajan, 'Asystasy,' for elaboration, as well as discussion of how Hunter and Schelling can be connected.

25. Schelling, First Outline, 149, 159; and Coleridge, Theory of Life, 495, 526.

26. Coleridge, Collected Letters, 4.667.

27. Krell, Contagion, 24.

28. William Wallace translated Parts 1 and 3 of the Encyclopedia $(1873,1894)$ but not the Philosophy of Nature. Twentieth-century translations of the three Jena systems also scrupulously omit the sections on nature.

29. Watson, Schelling's Transcendental Idealism, 92.

30. Esposito, Two, 3, 23-24, 33, 54-5, 77.

31. See Green, Vital Dynamics, xxi.

32. Ibid., v-ix, xiv-xv.

33. Ibid., 38n.

34. Ibid., 101-4. 
35. Schelling, First Outline, 53; for a fuller discussion see Rajan, 'Evolution and its Resistances,' 161-2.

36. Green, Vital Dynamics, 107.

37. Coleridge, Notebooks, 5.5478, 5489, 5510, 5518, 5522.

38. Coleridge, Theory of Life, 515; and Green, Vital Dynamics, 38-9.

39. Green, Vital Dynamics, xxii-iii.

40. Coleridge, Notebooks, 4.4517.

41. McFarland, 'Prolegomena,' cxlv-vi.

42. Levere, however, suggests Coleridge revised $T L$ in conjunction with Green's 1824 Hunterian lectures (Poetry Realized in Nature, 44-5).

43. Orsini, Coleridge and German Idealism, 198-200.

44. Schelling, 'Nature of Philosophy,' 217-20.

45. Hegel, Philosophy of Nature, 444.

46. Schelling, First Outline, 5-6; and 'Introduction to the Outline,' 196-7.

47. Schelling, Ideas, 30.

48. Coleridge, Biographia Literaria, 304-5.

49. Coleridge, Collected Letters, 4.874 .

50. Ibid., 4.874 .

51. Coleridge, Biographia Literaria, 163.

52. Schelling, 'Introduction to the Outline,' 194.

53. Coleridge, 'Friedrich Joseph Wilhelm von Schelling,' 4.374.

54. Coleridge, Notebooks, 3.4449; and Collected Letters, 4.873-4.

55. Schelling, Freedom, 66.

56. Ibid., 4.

57. Coleridge, Collected Letters, 4.793, 873-5. 
58. Modiano, Coleridge, 160, 186-204; and Hamilton, Coleridge and German Philosophy, 122-3.

59. Schelling, 'Nature of Philosophy,' 213, 217.

60. Coleridge, Collected Letters, 4.667, 792, 863.

61. Ibid., 4.864 .

62. Coleridge, Theory of Life, 516, 519n, 551.

63. Schelling, First Outline, 43, 53.

64. Ibid., 49.

65. Coleridge, Theory of Life, 510, 533; and Green, Vital Dynamics, 39.

66. Schelling, First Outline, 62, 160n.

67. Coleridge, Theory of Life, 538-9.

68. Coleridge, Notebooks, 4.4865; and Theory of Life, 539.

69. Schelling, First Outline, 127, 141, 149.

70. Coleridge, Theory of Life, 586; and The Friend, 1.474, 474n1.

71. Coleridge could not have read much by Hunter on life. The published work available by 1816-1819 was on gunshot wounds, venereal disease, and teeth but not comparative anatomy. Coleridge probably had an impression of Hunter's theories from John Abernethy, who sanitized him for his own purposes. Even organization of the Museum did not begin in earnest till 1823.

72. Coleridge, Theory of Life, 586; and Biographia Literaria, 300-4.

73. Coleridge, Theory of Life, 515, 557; and Notebooks, 3.4449. If Coleridge did indeed write $T L$ in 1819 (see note 22 above), he would just have been rereading $F O$.

74. Schelling, System of Transcendental Idealism, 122-6.

75. Schelling, First Outline, 35, 39-41, 53-4.

76. Coleridge, Theory of Life, 546-8.

77. Coleridge, Collected Letters, 6.597-8; and Scale of Life, 1194. 
78. This is Schelling's phrase in 'Vorlesungen' (261). The English translation in On University Studies(55) is imprecise.

79. Coleridge, History of Philosophy, 2.524-5.

80. Coleridge dissociated himself from EM, re-publishing his Introduction as the Essays on Method in The Friend. However, it is not the arrangement of volumes that annoyed him, but their mixed systematic-alphabetic arrangement, which brought EM closer to the Encyclopedia Britannica which it was supposed to counter.

81. Coleridge, Collected Letters, 6.599.

82. Krell, Contagion, 74-6, 94, 112-14.

83. See note 40 above.

84. Ibid., 4.4517, 4673.

85. Coleridge, Collected Letters, 6.599; and Notebooks, 4.4517 (cf. Collected Letters, 4.863).

86. Coleridge, Theory of Life, 519n.

87. Coleridge, History of Philosophy, 1.285-6.

88. Coleridge, Notebooks, 4.4517; and Foucault, Introduction to Kant's Anthropology, 120.

89. See note 40 above.

90. Ibid., 4.4728.

91. Schelling, On University Studies, 79-81.

92. For Coleridge's continued reading of Schelling, see Notebooks, 4.4641, 4776, 4778, 4839 See 4538, 4641, 4663, 4776, 4784, 4797, 4843, 4998, 5243, 5290,5406 , etc.

\section{Bibliography}

1. Amundson, R. The Changing Role of the Embryo in Evolutionary Thought: Structure and Synthesis. Cambridge: Cambridge University Press, 2005. 
2. Coleridge, S. T. Collected Letters. Edited by E. L.Griggs. 6 vols. Oxford: Clarendon, 1956-71.

3. Coleridge, S. T. The Notebooks of Samuel Taylor Coleridge. Edited by Kathleen Coburn and Anthony John Harding. 5 vols. Princeton: Princeton University Press, 1957-2002.

4. Coleridge, S. T. The Friend. Edited by Barbara Rooke. 2 vols. Princeton: Princeton

5. Coleridge, S. T. Biographia Literaria. Edited by James Engell and W. Jackson Bate. 2 vols. Princeton: Princeton University Press, 1983.

6. Coleridge, S. T. Theory of Life. Vol. 1 of Shorter Works and Fragments, 481-556. Edited by H. J. Jackson and J. R. de J. Jackson. Princeton: Princeton University Press, 1995.

7. Coleridge, S. T. 'Friedrich Joseph Wilhelm von Schelling.' In Marginalia, edited by George Whalley and H.J.Jackson, 344-364. Vol. 4. Princeton: Princeton University Press, 1998.

8. Coleridge, S. T. Lectures 1818-1819 on the History of Philosophy. Edited by J. R. de J. Jackson. 2 vols. Princeton: Princeton University Press, 2000.

9. Coleridge, S. T. Poetical Works: Poems (Reading Text) Part 1. Edited by J. C. C. Mays. Princeton: Princeton University Press, 2001.

10. Coleridge, S. T. Observations on the Scale of Life. Vol. 2 of Shorter Works and Fragments, 1193-1194.

11. Desmond, A. The Politics of Evolution: Morphology, Medicine and Reform in Radical London. Chicago: University of Chicago Press, 1989.

12. Esposito, R. Bios: Biopolitics and Philosophy. Translated by Timothy Campbell. Minneapolis: University of Minnesota Press, 2008.

13. Esposito, R. Immunitas: The Protection and Negation of Life. Cambridge: Polity Press, 2011.

14. Esposito, R. Two: The Machine of Political Theology and the Place of Thought. Translated by Zakiya Hanafi. New York: Fordham University Press, 2015.

15. Foucault, M. Introduction to Kant's Anthropology. Translated by Roberto Nigro and Kate Briggs. Los Angeles: Semiotext(e), 2008.

16. Green, J. H. Vital Dynamics: The Hunterian Oration before the Royal College of Surgeons in London, 17th February 1840. London: William Pickering, 1840.

17. Green, J. H. Mental Dynamics or Groundwork of a Professional Education, the Hunterian Oration before the Royal College of Surgeons of England, 15th Feb 1847. London: William Pickering, 1847.

18. Green, J. H. Spiritual Philosophy: Founded on the Teaching of the Late Samuel Taylor Coleridge. Edited by John Simon. 2 vols. London: Macmillan, 1865.

19. Green, J. H. 'Introduction to the Natural History of Birds, Tues. 27 March, 1827.' In The Hunterian Lectures in Comparative Anatomy May and June 1837, edited by R. Owen and Phillip Sloan, 307-321.

20. Hamilton, P. Coleridge and German Philosophy. London: Bloomsbury, 2007.

21. Hegel, G. W. F. Lectures on the History of Philosophy. Translated by E. S. Haldane and Frances H. Simson. 3 vols. Reprint, Lincoln: University of Nebraska Press, 1995.

22. Hegel, G. W. F. Philosophy of Nature. Translated by A. V. Miller. Oxford: Clarendon, 1970.

23. Hunter, W. B. 'The Seventeenth-Century Doctrine of Plastic Nature.' Harvard Theological Review 43, no. 3 (1950): 197-213. doi:10.1017/S0017816000024512. 
24. Krell, D. F. Contagion: Sexuality, Disease, Ad Death in German Idealism and Romanticism. Bloomington: Indiana University Press, 1998.

25. Levere, T. Poetry Realized in Nature: Samuel Taylor Coleridge and Early NineteenthCentury Science. Cambridge: Cambridge University Press, 1981.

26. McFarland, T. 'Prolegomena' to S.T. Coleridge, Opus Maximum. Edited by Thomas McFarland. Princeton: Princeton University Press, 2002.

27. Modiano, R. Coleridge and the Concept of Nature. Tallahassee: Florida State University Press, 1985.

28. Orsini, G. N. G. Coleridge and German Idealism: A Study in the History of Philosophy. Carbondale: Southern Illinois University Press, 1969.

29. Owen, R. On the Nature of Limbs (1849). Edited by Ron Amundson. Chicago: University of Chicago Press, 2007.

30. Rajan, T. 'Evolution and Its Resistances: Transferences between Disciplines in Hegel's and Schelling's Systems.' Symposium: Canadian Journal of Continental Philosophy 19, no. 1 (2015): 153-175. doi:10.5840/symposium201519112.

31. Rajan, T. 'The Asystasy of the Life Sciences: Schelling, Hunter and British Idealism.' Kabiri: Journal of the North American Schelling Society, 1, September 2017. http://journals.library.mun.ca/ojs/index.php/kabiri.

32. Richards, R. The Romantic Conception of Life: Science and Philosophy in the Age of Goethe. Chicago: University of Chicago Press, 2002.

33. Schelling, F. W. J. On University Studies. Translated by E. S. Morgan and edited by Norbert Gutterman. Athens: University of Ohio Press, 1966.

34. Schelling, F. W. J. System of Transcendental Idealism. Translated by Peter Heath. Charlottesville: University Press of Virginia, 1978.

35. Schelling, F. W. J. Ideas for a Philosophy of Nature (1797/1803). Translated by Errol E. Harris and Peter Heath. Cambridge: Cambridge University Press, 1988.

36. Schelling, F. W. J. 'On the Nature of Philosophy as Science.' In German Idealist Philosophy, edited by R. Bübnerand translated by Marcus Bullock, 210243. Harmondsworth: Penguin, 1997.

37. Schelling, F. W. J. 'Vorlesungen uber die Methode des akademischen Studiums.' In Sammtliche Werke, edited by E. Hahn. Total Verlag, 1997. CD-Rom. 1.5.207-353.

38. Schelling, F. W. J. The Ages of the World (1815 Version). Translated by Jason M. Wirth. Albany: State University of New York Press, 2000.

39. Schelling, F. W. J. First Outline of a System of the Philosophy of Nature. Translated by Keith Peterson. Albany: State University of New York Press, 2004.

40. Schelling, F. W. J. Philosophical Investigations into the Essence of Human Freedom (1809). Translated by Jeff Love and Johannes Schmidt. Albany: State University of New York Press, 2006.

41. Schelling, F. W. J. 'Introduction to the Outline of a System of the Philosophy of Nature.' In First Outline, 193-232.

42. Watson, J. Schelling's Transcendental Idealism. A Critical Exposition. Chicago: S.C.Griggs, 1882. 


\section{Additional information}

\section{Author information}

\section{Tilottama Rajan}

Tilottama Rajan is a Canada Research Chair and Distinguished University Professor at the University of Western Ontario. She is the author of four monographs (most recently Romantic Narrative [Johns Hopkins, 2010]), editor or coeditor of seven books (most recently Idealism Without Absolutes [SUNY, 2004]), and author of over a hundred articles on Romantic literature, German Idealist and Romantic philosophy, and Contemporary Theory. Her current interest is in organizations of knowledge. She is working on a book on entangled knowledge from Idealism to Deconstruction.

\section{Funding}

This work was supported by the Canada Research Chairs. 